\title{
Heat Transfer Optimization in Air Flat Plate Solar Collectors Integrated with Baffles
}

\author{
Ramadhani Bakari \\ Department of Petroleum and Energy Engineering, University of Dodoma, Dodoma, Tanzania \\ Email: ramaringo2006@yahoo.co.uk
}

How to cite this paper: Bakari, R. (2018) Heat Transfer Optimization in Air Flat Plate Solar Collectors Integrated with Baffles. Journal of Power and Energy Engineering, 6, 70-84.

https://doi.org/10.4236/jpee.2018.61006

Received: August 25, 2017

Accepted: January 28, 2018

Published: January 31, 2018

Copyright $\odot 2018$ by author and Scientific Research Publishing Inc. This work is licensed under the Creative Commons Attribution International License (CC BY 4.0).

http://creativecommons.org/licenses/by/4.0/

\begin{abstract}
This paper presents an experimental analysis for comparisons of conventional flat plate solar collectors and collectors integrated with different numbers of baffles. Heat transfer between absorber plate and drying fluid (air) has been one of the major challenges in the design and operations of the indirect solar dryer systems. In this experiment, efficiency of air flat plate solar collector integrated with 2, 3, 4 and 8 baffles was studied and compared with the ordinary collector. The results showed that integrating solar collector with baffles significantly increased the efficiency of the system. It was noted that collector with 2, 3, 4 and 8 baffles had a mean efficiency of $29.2 \%, 31.3 \%, 33.1 \%$ and $33.7 \%$ respectively while with no baffles was $28.9 \%$. The analysis showed that when there were less than four baffles in the collector, heat transfer was dominant over pressure drop and hence high efficiency. However, when the number of baffles exceeded four, the effect associated with an increase in pressure drop highly observed compared to heat transfer coefficient, thus resulted to insignificant increase in efficiency. Therefore, the optimum number of four baffles was commended for the designed model for optimum efficiency.
\end{abstract}

\section{Keywords}

Solar Collector, Solar Dryer, Sun Drying, Collector Efficiency, Heat Transfer

\section{Introduction}

Open sun drying for the preservation of agricultural, food and many other products has been popular in many societies from ancient time [1]. Although the practice is economical, controlling external parameters such as heat input, moisture content, temperature etc. is very challenging [2]. The idea of solar dryer has become the ideal approach to overcome the challenges of open sun drying. The 
method has become an alternative to the marketing of fresh perishable products which have increased demands from day to day [3]. Solar dryer offers the effective, cheap, and environment-friendly approach of preserving agricultural and food products [4].

It is known that important quality verdict made by consumers on dried food in the market is its visual appearance and sensory quality, which includes: colour, flavour, taste, texture and aroma [5]. Therefore, the dried food should have the suitable appearance and sensory quality in order to be accepted in the competitive market. The challenges of open sun drying such as contamination by insects and micro-organisms; damage by animals, mould growth, discolouration, and distraction of vitamin and difficulty in setting uniform and standard of end-products have pushed the researcher to develop different scientific methods of solar energy utilization for crop drying [5] [6] [7] [8]. The use of solar dryer systems in agricultural areas to conserve vegetables, fruits, and other crops has shown to be practical in terms of investment cost, hygienic, improved product quality and an environmentally friendly approach [9].

\section{Indirect Solar Dryer System}

Indirect cabinet solar dryer with forced convection flow is one of the best solar drying technologies which can produce high-quality products and eliminate the risk of discolouration and distraction of vitamins [10] [11]. This dryer mode generally comprises of solar collector, drying unit, a fan, and ducting for air circulation [2]. The use of this type of dryer can reduce drying time by three times compared to other types of dryers and reduce the required collector area by $50 \%$ [12]. Numerous indirect solar dryers have been designed and constructed; however, their utilization is still limited due to their poor performance [13]. Important criteria for adoption of this type of dryers include short drying time, low investment costs and improved quality of products. In recent years, several indirect solar dryers have been constructed in Tanzania, however, their utilization has been very minimal and some of them are abandoned after a short period of use [14]. Solar air collectors, although they are a very important component of the solar dryer system, have not paid much consideration during dryer design and construction [15]. The effectiveness of flat plate solar collectors is a function of climatic conditions and design parameters such as the thickness of cover material, collector orientation, collector depth, type of absorber materials used and collector geometry [16] [17] [18]. Irrespective of many types of research on solar collectors, factors such as glazing thickness, type of absorbing materials and heat transfer mechanisms have not well been considered during collector construction [19]. Therefore, there is a need to study different materials for solar collector construction as well as heat transfer mechanisms in the collector in order to improve its performance. This study aims to address the challenges of heat transfer in the collector for the purposes of increasing the efficiency of the drying system. 


\section{Literature Review}

The solar collector is a kind of duct heat exchanger that transfers heat energy from incident solar radiation to the fluid passing through it. It absorbs solar radiation through glazing, converting it to heat energy and transferring it to a working fluid [20]. The collector comprises of absorber plate in a flat rectangular housing, glass cover on the upper surface and the insulation on other sides to limit the thermal losses. The solar energy absorbed by the plate is transferred to the fluid flowing within the collector channel [21]. To have effective thermal efficiencies of a flat plate solar collector, heat has to be efficiently transferred from the absorber plate to the flowing air. Heat transfer coefficient inside the solar collector is an important parameter that affects the efficiency of the collector [22]. Researchers have recommended various modifications to enhance heat transfer rate in solar collector by incorporating different modifications between absorber plate and glass plate [23].

\subsection{Influence of Baffles in Heat Transfer}

Baffles provide an additional heat transfer surface area and promote air turbulence in the collector. The presence of baffles causes the air flow to separate, reattach and create a reverse flow which increasing the heat washing action. The main concept of integrating collector with baffles is to reduce dead zones and increase heat transfer area.

Figure 1 and Figure 2 show visualization model of collectors with and without baffles as shown as presented by [24]. Figure 1 illustrates airflows patterns in a collector without baffles, it can be observed that there is straight airflow in the aperture of the absorber from the inlet toward outlet which creates many dead zones. This means that there is no enough retention time between air and absorber to allow the effectiveness of heat transfer. On the other hand, Figure 2 shows the formation of a meandering flow of air in the collector with baffles from the inlet to the outlet. In this case, it is clear that the length of air trajectory is more than double that of the length of the collector, thus increasing the heat transfer and effectively reducing dead zones.

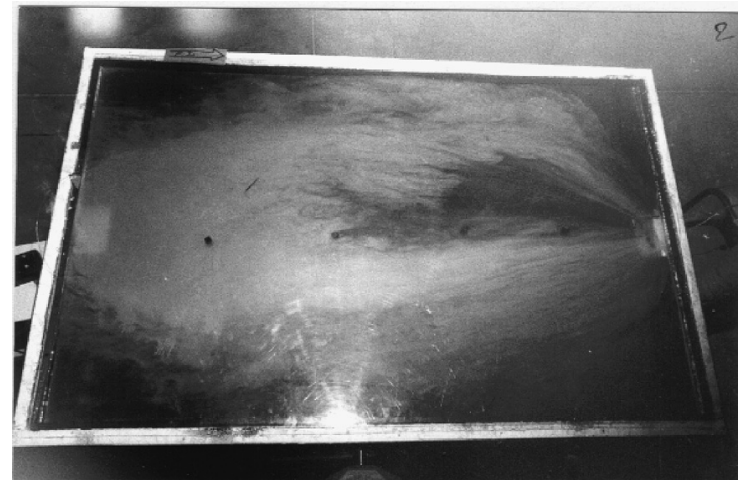

Figure 1. Visualization of the air flow in the collector without baffles. 


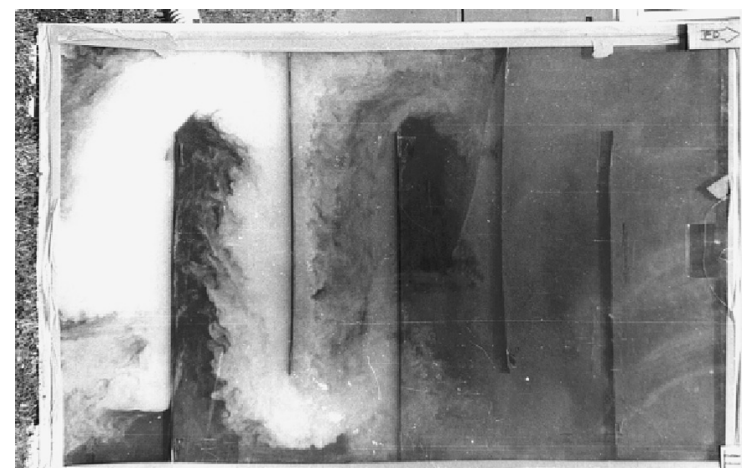

Figure 2. Visualization of air flow in the collector with baffles.

Important of baffles in solar dryers system was also reported by Pona [25] in his research and recommended the installation of baffles raise the efficiency of the collector by $7 \%$ to $12 \%$ compared to ordinary collectors (collector without baffles). Similarly, Abene [26] assesses heat transfer in collector by inserting different types of air obstacles disposed of in rows across the plate of collector and reported positive improvement of the performance of the drying unit. Furthermore, [27] experimentally studied the impact of baffle space and baffle length in the performance of solar collector. It was found that increasing baffle length and decreasing baffle space increases the performance of solar collector. However, the reported studies have shown promising output in enhancing collector heat transfer, the optimum baffle space and length has not been reported. It can be seen that baffles reduce air space channel situated between the insulator and the absorber and increase the friction with the contact surfaces all of which increases pressure drop. Consequently, increased pressure drop increases fixed charge and fan power which leads to increased operating cost. Therefore, designing and installation of baffles should be economically feasible for easy adaptation.

\subsection{Efficiency of Flat Plate Solar Collectors}

The thermal efficiency of the flat plate solar collector is the ratio of the energy out of the collector to the total incident solar radiation averaged over the same time interval. Mathematically, the efficiency $(\eta)$ of a collector is expressed by Equation (1) [28] [29].

$$
\eta=\frac{\text { useful energy }}{\text { solar energy available }}
$$

The outlet energy (useful energy) for a solar thermal collector is the rate of thermal energy leaving the collector, usually described in terms of the rate of energy being added to a heat transfer fluid passing through the receiver or absorber.

$$
Q_{u}=m \cdot C_{p} \cdot\left(T_{o}-T_{i}\right)
$$

The area of the collector on which the solar irradiance falls is called the aperture area of the collector. Therefore, total energy received by the collector (opti- 
cal energy captured) can be described by Equation (3).

$$
Q_{\text {in }}=I \cdot A
$$

Accordingly, absorptance and transmittance are multiple effects of optical energy capture and therefore, these factors indicate the percentage of the solar rays penetrating the transparent cover of the collector and the percentage being absorbed.

$$
Q_{i n}=\alpha \cdot \tau \cdot I \cdot A
$$

The rate of useful energy of the collector can be expressed by using overall heat loss coefficient and the collector temperature as Equation (5).

$$
\dot{Q}_{\text {useful }}=\dot{Q}_{i n}-\dot{Q}_{\text {loss }}=\alpha \cdot \tau \cdot I \cdot A-U_{L} \cdot A_{C} \cdot\left(T_{c}-T_{a}\right)
$$

Since it is difficult to define the collector average temperature in Equation (5), it is convenient to define a quantity that relates the actual useful energy gain of a collector to the useful gain if the whole collector surface were at the fluid inlet temperature [28]. This quantity is known as "the collector heat removal factor $\left(F_{R}\right)$ " and is expressed by Equation (6).

$$
F_{R}=\frac{\dot{m} \cdot C_{p} \cdot\left(T_{o}-T_{i}\right)}{A \cdot\left[\alpha \cdot \tau \cdot I-U_{L} \cdot\left(T_{i}-T_{a}\right)\right]}
$$

Finally, the equation for the efficiency of flat plate solar collector can be given by "Hottel-Whillier-Bliss equation" [30].

$$
\eta=F_{R} \cdot \alpha \cdot \tau-F_{R} \cdot U_{L} \cdot\left(\frac{T_{i}-T_{a}}{I}\right)
$$

If it is assumed that $\tau$ and $\alpha$ are constants for a given collector and flow rate, then the collector efficiency is a linear function of the three parameters defining the operating condition: Solar irradiance (I), Fluid inlet temperature $\left(T_{i}\right)$ and collector outlet temperature $\left(T_{o}\right)$. Thus, the performance of a Flat-Plate Collector can be approximated by experimentally measuring these three parameters, and the efficiency can be calculated by using summarized Equation (8) [31].

$$
\eta=\frac{\dot{m} \cdot C_{p}}{A} *\left[\frac{T_{o}-T_{i}}{I}\right]
$$

\section{Methodology}

Four similar flat plate solar collector models were constructed by using Pterocarpus timber which functions as the frame of collector and insulator. The thickness of side walls of the collectors were 2 inches with black painted marine plywood as absorber materials. Absorber plates were well protected with foodstandard waterproof material and both collectors were covered by $4 \mathrm{~mm}$ glass thickness. Geometrical specifications of collectors were: collector length to width ratio 2 (length $1.2 \mathrm{~m}$ and width $0.6 \mathrm{~m}$ ), depth $12 \mathrm{~cm}$ and length of baffles covered $85 \%$ of collector width. Both Collectors were oriented to the north-south direction and tilted to an angle of $6^{\circ}$ (latitude angle of Dar es Salaam) with the 
ground toward the north direction to receive maximum solar radiation and to avoid rainy water accumulation inside the collector (Figure 3).

The temperatures in the collector were measured by using multichannel XR5-SE data logger connected with PT940 temperature sensors whilst ambient temperatures were measured by CEM DT-172 temperature and humidity data logger. On the other hand, solar intensity and air flow rate were respectively measured by using PCE-SPM solar radiation meter and Testo-425 Hot Wire Thermo-Anemometer. Table 1 gives the precision of the measuring devices used in this study.

Air flows in the collectors were controlled by extract fans which were attached to the outlet duct. Experiments were conducted daily from 7:00 am before sunrise to $6: 00 \mathrm{pm}$ after sunset. Data were filtered by removing the data with some interruptions such as rainy days and power cuts.

Collector models were integrated with 2, 3, 4, 8 baffles respectively, their efficiencies were measured and compared with the collector with no baffles (conventional collectors). Baffles were equally spaced over the collector geometry as shown in Figure 4 and Figure 5.

\section{Results and Discussion}

\subsection{Temperature Profiles}

Figure 6 is the representation of temperature and solar intensity comparisons

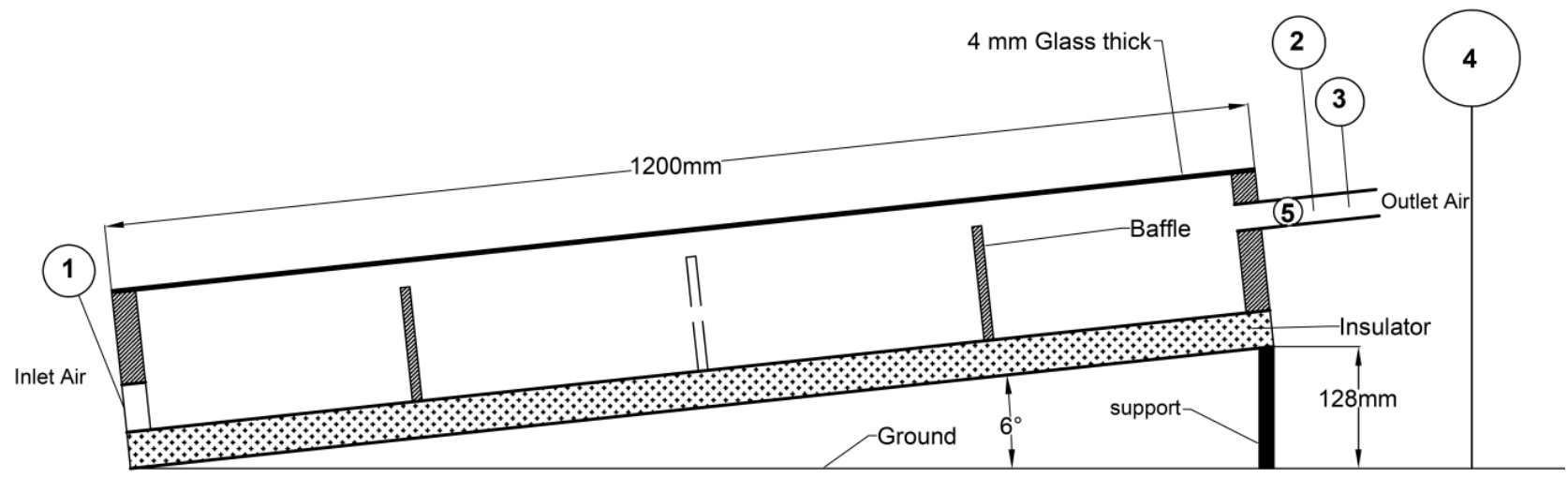

Where: 1: CEM DT-172 temperature and humidity data logger

2: PT940 temperature sensor

3: Testo 425 Hot Wire Thermal Anemometer

4: PCE-SPM solar radiation meter 5: Extract fun

Figure 3. Schematic side view of collector model.

Table 1. Precision of data measuring devices used in this study.

\begin{tabular}{cc}
\hline Measuring devices & Accuracy \\
\hline XRe-SE data logger & $\pm 0.15^{\circ} \mathrm{C}$ from $10^{\circ} \mathrm{C}$ to $40^{\circ} \mathrm{C} ; \pm 0.3^{\circ} \mathrm{C}$ from -25 to $85^{\circ} \mathrm{C}$ \\
PCE-SPM solar radiation meter & $\pm 10 \mathrm{~W} / \mathrm{m}^{2}$ or $\pm 5 \%$ (more accuracy in highest value) \\
CEM DT-172 temperature and humidity data logger & Temp $\pm 1^{\circ} \mathrm{C}$ and Humid $\pm 2 \%$ \\
Testo- 425 hot wire thermal anemometer & $\pm(0.03 \mathrm{~m} / \mathrm{s})$ \\
\hline
\end{tabular}




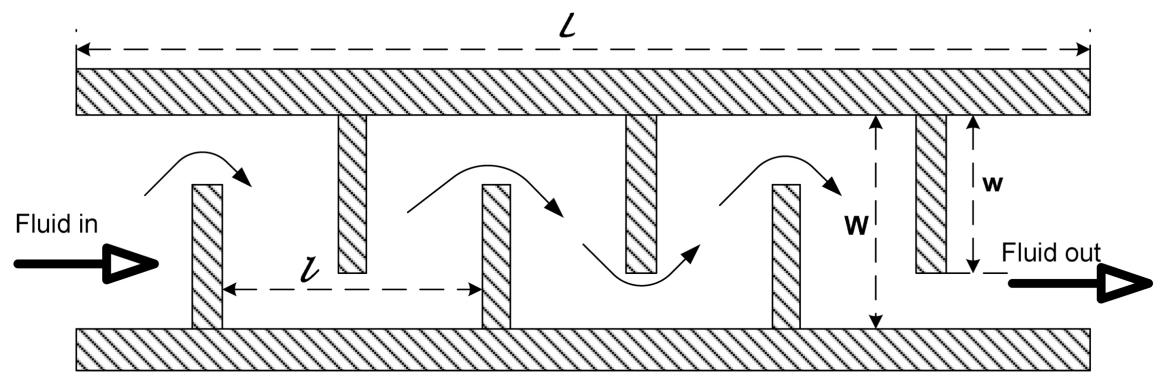

Figure 4. Schematic top view of collector with baffles. Length $(\mathrm{L})=1.2 \mathrm{~m}$, length of baffles $(w)=85 \%$ width of collector and collector width $(\mathrm{W})=0.6 \mathrm{~m}$.
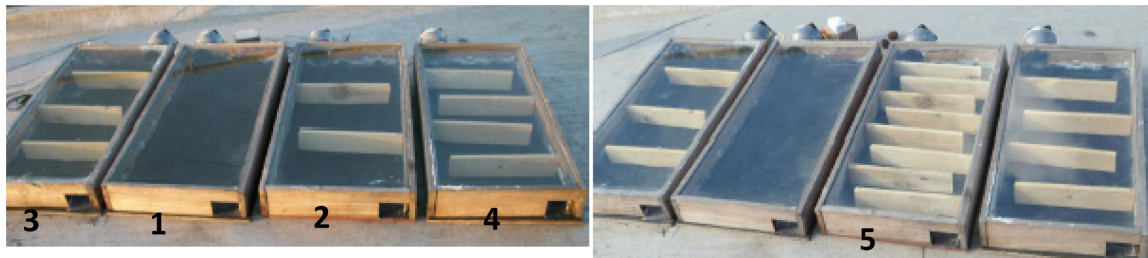

Figure 5. Collector models with installed baffles: Model-1: ordinary collector, Model-2: collector with 2 baffles, Model-3: collector with 3 baffles, Model-4: collector with 4 baffles and Model-5: collector with 8 baffles.

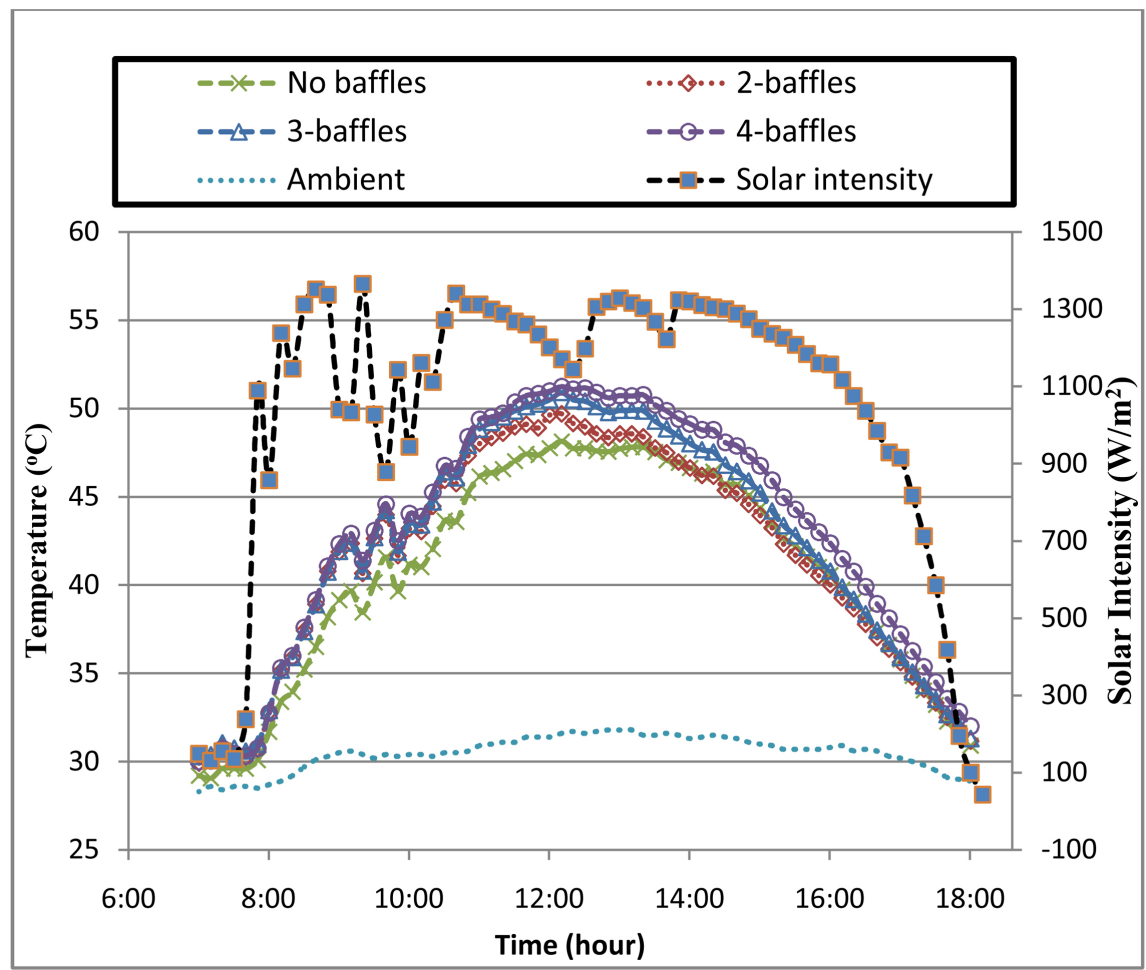

Figure 6. Temperature profiles and solar intensity for ordinary collector and collector with 2,3 and 4 baffles.

for ordinary collectors and with 2, 3 and 4 baffles. It can be seen that collector with 4 baffles gave high temperature along the day compared to the ordinary collector and with 2 and 3 baffles. The model with 4 baffles gave an average 
temperature of $42.7^{\circ} \mathrm{C}$ while that with 2,3 and without baffles gave $42.1^{\circ} \mathrm{C}$, $41.6^{\circ} \mathrm{C}$, and $40.1^{\circ} \mathrm{C}$ respectively. On the other hand, the maximum temperature reached in collector with 4 baffles were $52.2^{\circ} \mathrm{C}$ while that of the collector with 2 , 3 and without baffles were respectively $50^{\circ} \mathrm{C}, 51^{\circ} \mathrm{C}$, and $48^{\circ} \mathrm{C}$.

On the other hand, Figure 7 shows variations of temperatures in collectors without baffles and with 3, 4 and 8 baffles. Collector model with 8 baffles showed superiority in outlet temperature compared to other models. The average temperature for the collector with 8 baffles was $41.3^{\circ} \mathrm{C}$ while that of 3,4 and without baffles were $39^{\circ} \mathrm{C}, 40^{\circ} \mathrm{C}$, and $38^{\circ} \mathrm{C}$ respectively. The figure showed the high fluctuation of temperature which was caused by instability of solar intensity. In this regards, it can be seen that the collector temperature cannot be used as a comparative parameter in a solar collector with and without baffles due to the variation of solar intensity and air flow due to change in fan efficiency.

During the morning, the sky is normally covered by clouds, which resulted into high fluctuation of solar intensity compared to the afternoon. In some cloudy days, the fluctuations were prolonged along the day as indicated in Figure 7. The average solar intensity in all days of the experiment was $818 \mathrm{~W} / \mathrm{m}^{2}$ while the maximum solar intensity recorded was $1425 \mathrm{~W} / \mathrm{m}^{2}$.

The rate of change in temperature at the interval of 10 minutes is shown in Figure 8. There was a high-temperature change from morning to noon, which was caused by instability of solar intensity and low angle $\left(0^{\circ}-60^{\circ}\right)$ of insolation to the collector surface. Also, during this time most of the energies absorbed by the collector were used in pre-heating the collector parts. Fluctuation of temperature was then reduced from noon due to good insolation angle to the collector surface (greater than $60^{\circ}$ ), system equilibrium and less effect of fluctuation

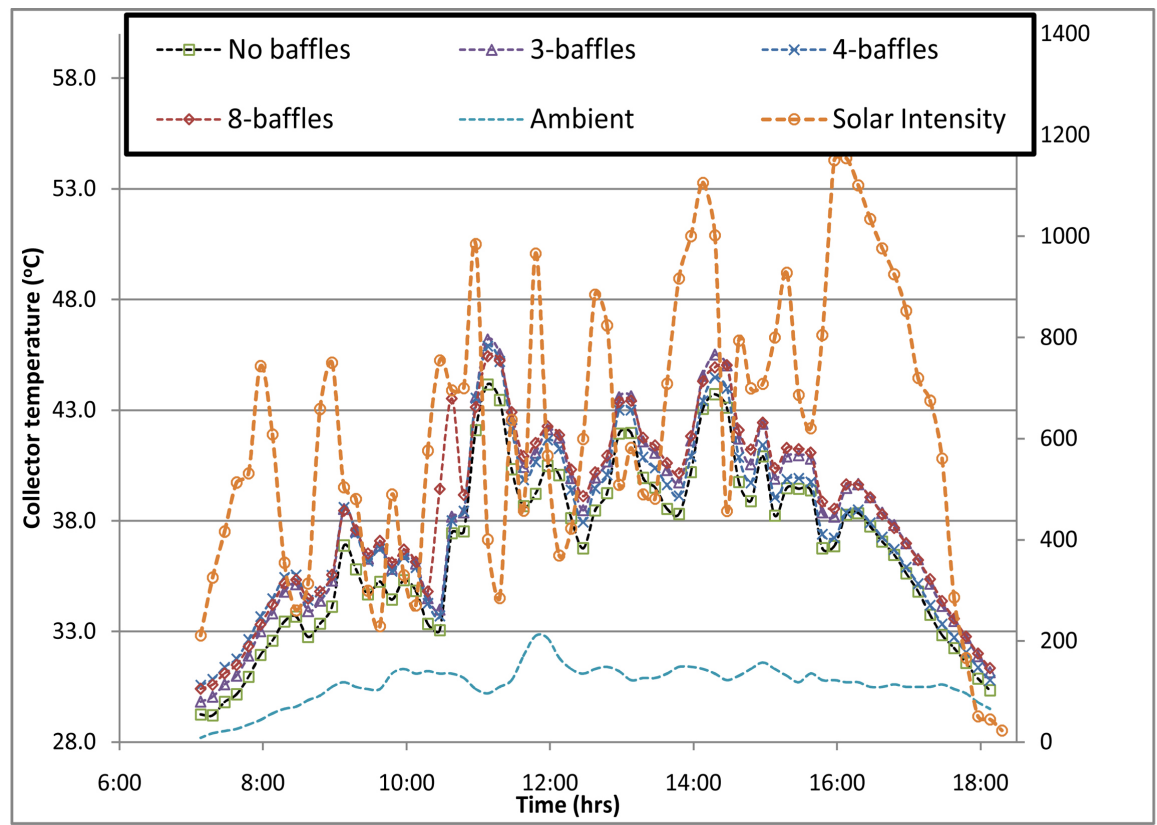

Figure 7. Temperature profiles and solar intensity for ordinary collector and collector with 3,4 and 8 baffles. 


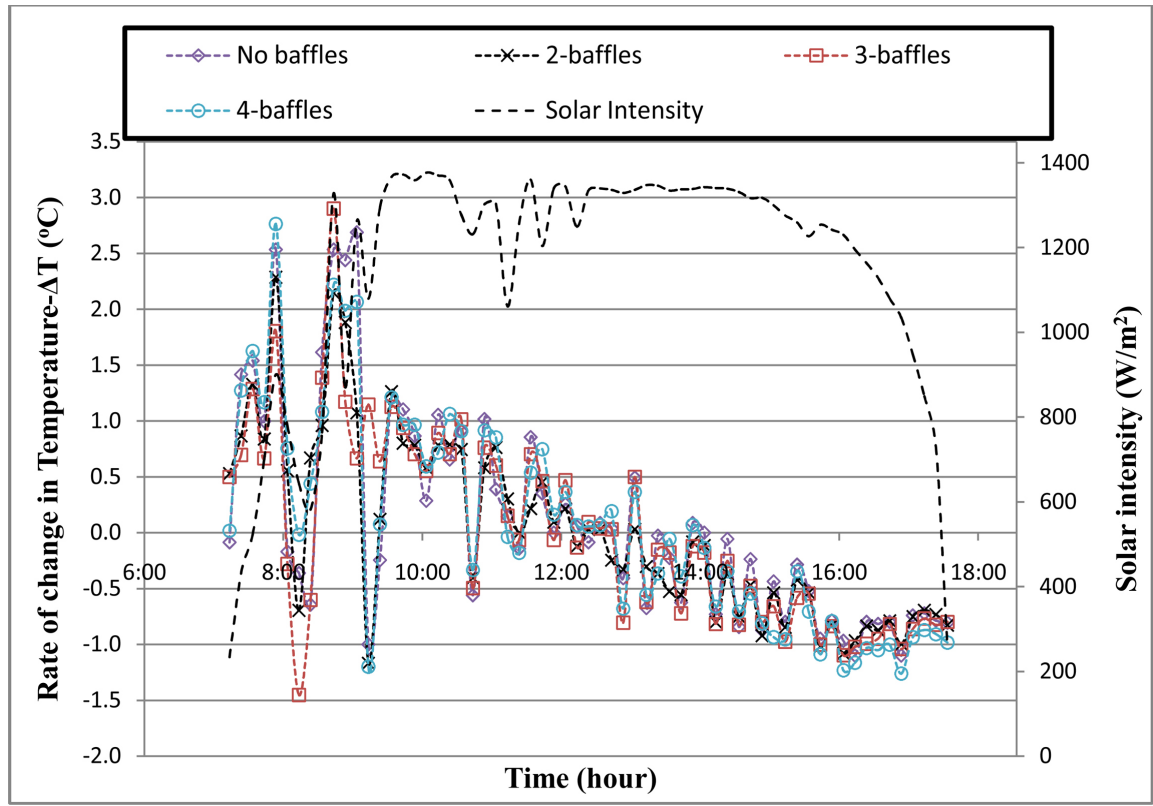

Figure 8. Rate of change in temperature along the day.

of solar intensity.

\subsection{Energy Profiles for Collector with Different Number of Baffles}

Generally, collected energy varies with the fluctuation of solar intensity and when solar intensity increases, the collector's energy also increased. Low energy during the morning and sunset were caused by the low solar incidence angle to the collector surface and the fact that during the morning most of the collected heat was used in preheating the system. In addition, fluctuations of energy during the afternoon were due to poor thermal heat storage behaviour of the absorbing material.

\subsection{Analysis of Efficiency of Collector with Different Number of Baffles}

The results of the statistical analysis of variance (ANOVA) for the collector with a different number of baffles (different ratio of baffle space to collector length) which was carried out to study the significance differences between their individual means are reported in Table 2. Mean efficiencies are 29.2\%, 31.3\%, 33.1\%, $33.7 \%$ and $28.9 \%$ for collector with $2,3,4,8$ and with no baffles respectively. It is clear that collector efficiencies were continued improved with an increase in a number of baffles. The highest thermal efficiency as analysed by SPSS program was $33.7 \%$ in collector with 8 -baffles while the lowest efficiency was $28.9 \%$ for collector without baffles.

\subsection{Mean Efficiency Comparisons for Collector with Different Number of Baffles}

A one-way between subject ANOVA was used to compare the effect of varying 
Table 2. Statistical analysis of performance of solar air collector by using SPSS.

\begin{tabular}{|c|c|c|c|c|c|c|c|c|}
\hline & \multirow{2}{*}{$\mathrm{N}$} & \multirow{2}{*}{$\begin{array}{c}\text { Mean } \\
\text { efficiency }\end{array}$} & \multirow{2}{*}{$\begin{array}{c}\text { Std. } \\
\text { deviation }\end{array}$} & \multirow{2}{*}{$\begin{array}{l}\text { Std. } \\
\text { error }\end{array}$} & \multicolumn{2}{|c|}{$\begin{array}{l}95 \% \text { Confidence } \\
\text { interval for mean }\end{array}$} & \multirow{2}{*}{ Min. } & \multirow{2}{*}{ Max. } \\
\hline & & & & & Lower bound & $\begin{array}{l}\text { Upper } \\
\text { bound }\end{array}$ & & \\
\hline No-baffles & 10 & 29.00 & 1.93129 & 0.61073 & 27.5084 & 30.2716 & 28.20 & 30.40 \\
\hline 2-baffles & 7 & 29.214 & 1.91349 & 0.72323 & 27.4446 & 30.9840 & 29.10 & 31.70 \\
\hline 3-baffles & 10 & 31.290 & 2.34400 & 0.74124 & 29.6132 & 32.9668 & 29.80 & 34.80 \\
\hline 4-baffles & 10 & 33.140 & 2.67798 & 0.84685 & 31.2243 & 35.0557 & 30.30 & 38.70 \\
\hline 8-baffles & 3 & 33.700 & 3.77227 & 2.17792 & 24.3292 & 43.0708 & 30.60 & 37.90 \\
\hline Total & 40 & 30.970 & 2.92340 & 0.46223 & 30.0351 & 31.9049 & 26.10 & 38.70 \\
\hline $\begin{array}{l}\text { Fixed } \\
\text { effects }\end{array}$ & & & 2.37842 & 0.37606 & 30.2066 & 31.7334 & & \\
\hline $\begin{array}{l}\text { Random } \\
\text { effects }\end{array}$ & & & & 0.97645 & 28.2589 & 33.6811 & & \\
\hline
\end{tabular}

baffles number on the efficiency of the collector. The comparisons were done to ascertain if there is a significant difference between collector's efficiencies.

From Table 3, significance value $\mathrm{P}<0.05$, thus it can statistically be concluded that there was a significant difference between the means of collector efficiency with and without baffles. However, in order to identify which baffle number gave significant difference, a post-hoc test for multiple comparisons was conducted. Table 4 shows the results of Levene's Test for Equality of Variances (LTEV) which was used to ascertain the method to use in multiple comparison tests.

Since the significance value for Levene test for equity of variance is 0.729 which means $(\mathrm{P}>0.5)$, therefore, equal variance assumed (Tukey HSD) were used for multiple comparisons of means of collector efficiency.

Table 5 shows significant different when comparing collector with 4 and 8 baffles to the collector without baffles, $p=0.003$ and $p=0.031$ respectively. Likewise, there was a significant difference when comparing collector with 4 and 2 baffles $(\mathrm{p}=0.016)$.

The purpose of introducing baffles in the collector duct was to create turbulence so as to increase heat transfer coefficient and hence the collector's efficiency. In this study, baffles played a big role in collector heat transfer rate by forcing air to take longer meandering trajectory than the normal length of collector and forcing air to circulate through space left between baffles. On the other hand, the presence of baffles caused the flow to separate, re-attach and create a reverse flow which was increasing the heat transfer action from the absorber to air as. The flowing air was also forced by baffles to pass onto the warm wall of the absorber surface which resulted in good heat transfer and a considerable increase in output temperature. It was further observed that reducing the baffles spacing by increasing the number of baffles considerably increases 
Table 3. Analysis of variance for collector with different baffles and without baffles.

\begin{tabular}{cccccc}
\hline & Sum of squares & df & Mean square & F & Sig. \\
\hline Between groups & 135.313 & 4 & 33.828 & 5.980 & 0.001 \\
Within groups & 197.991 & 35 & 5.657 & & \\
Total & 333.304 & 39 & & & \\
\hline
\end{tabular}

Table 4. Results for LTEV for collector with and without baffles.

\begin{tabular}{cccc}
\hline Levene statistic & df1 & df2 & Sig. \\
\hline 0.510 & 4 & 35 & 0.729 \\
\hline
\end{tabular}

Table 5. Multiple comparisons test for means efficiency of collector with and without baffles.

\begin{tabular}{|c|c|c|c|c|c|c|}
\hline \multirow[b]{2}{*}{ (I) Baffles } & \multirow[b]{2}{*}{ (J) Baffles } & \multirow{2}{*}{$\begin{array}{c}\text { Mean } \\
\text { difference (I-J) }\end{array}$} & \multirow[b]{2}{*}{ Std. error } & \multirow[b]{2}{*}{ Sig. } & \multicolumn{2}{|c|}{$95 \%$ confidence interval } \\
\hline & & & & & $\begin{array}{l}\text { Lower } \\
\text { bound }\end{array}$ & $\begin{array}{l}\text { Upper } \\
\text { bound }\end{array}$ \\
\hline \multirow{4}{*}{ 0-baffles } & 2-baffles & -0.32429 & 1.17210 & 0.999 & -3.6941 & 3.0456 \\
\hline & 3-baffles & -2.40000 & 1.06366 & 0.183 & -5.4581 & 0.6581 \\
\hline & 4-baffles & $-4.25000^{*}$ & 1.06366 & 0.003 & -7.3081 & -1.1919 \\
\hline & 8-baffles & $-4.81000^{*}$ & 1.56567 & 0.031 & -9.3114 & -0.3086 \\
\hline \multirow{4}{*}{ 2-baffles } & 0-baffles & 0.32429 & 1.17210 & 0.999 & -3.0456 & 3.6941 \\
\hline & 3-baffles & -2.07571 & 1.17210 & 0.406 & -5.4456 & 1.2941 \\
\hline & 4-baffles & $-3.92571^{*}$ & 1.17210 & 0.016 & -7.2956 & -0.5559 \\
\hline & 8-baffles & -4.48571 & 1.64126 & 0.069 & -9.2044 & 0.2330 \\
\hline \multirow{4}{*}{ 3-baffles } & 0-baffles & 2.40000 & 1.06366 & 0.183 & -0.6581 & 5.4581 \\
\hline & 2-baffles & 2.07571 & 1.17210 & 0.406 & -1.2941 & 5.4456 \\
\hline & 4-baffles & -1.85000 & 1.06366 & 0.424 & -4.9081 & 1.2081 \\
\hline & 8-baffles & -2.41000 & 1.56567 & 0.545 & -6.9114 & 2.0914 \\
\hline \multirow{4}{*}{ 4-baffles } & 0-baffles & $4.25000^{*}$ & 1.06366 & 0.003 & 1.1919 & 7.3081 \\
\hline & 2-baffles & $3.92571^{*}$ & 1.17210 & 0.016 & 0.5559 & 7.2956 \\
\hline & 3-baffles & 1.85000 & 1.06366 & 0.424 & -1.2081 & 4.9081 \\
\hline & 8-baffles & -0.56000 & 1.56567 & 0.996 & -5.0614 & 3.9414 \\
\hline \multirow{4}{*}{ 8-baffles } & 0-baffles & $4.81000^{*}$ & 1.56567 & 0.031 & 0.3086 & 9.3114 \\
\hline & 2-baffles & 4.48571 & 1.64126 & 0.069 & -0.2330 & 9.2044 \\
\hline & 3-baffles & 2.41000 & 1.56567 & 0.545 & -2.0914 & 6.9114 \\
\hline & 4-baffles & 0.56000 & 1.56567 & 0.996 & -3.9414 & 5.0614 \\
\hline
\end{tabular}

${ }^{*}$ The mean difference is significant at the 0.05 level.

the collector efficiency.

From this study, a collector with 8 baffles gave the highest efficiency of 33.7\%, while that of 4,3 , and 2 and with no baffles were $33.1 \%, 31.3 \%, 29.2 \%$ and $28.9 \%$ respectively.

Figure 9 shows the effect of the ratio of baffle spacing to collector length in 


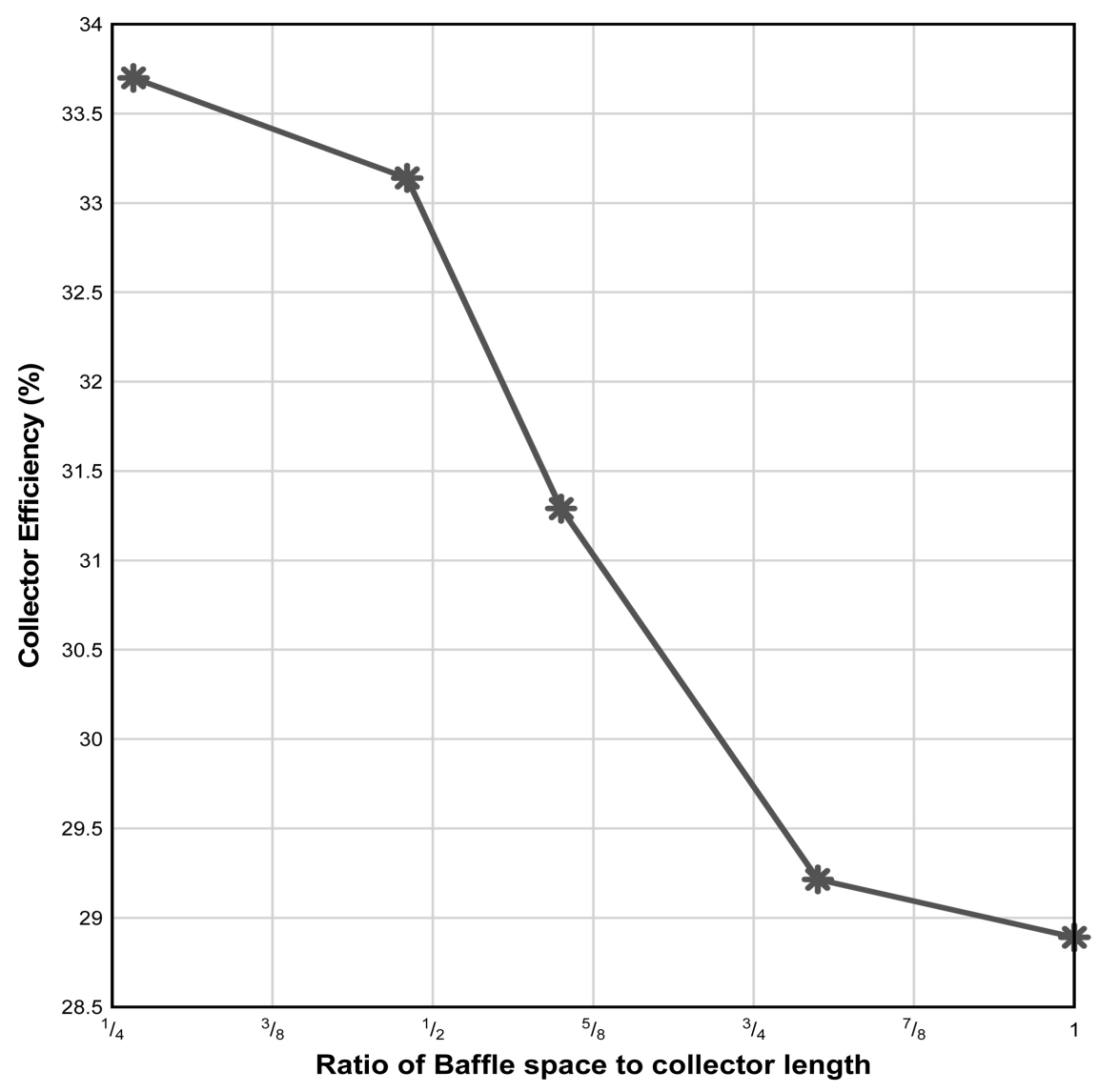

Figure 9. Comparison of ratio of baffle space and collect length to collector efficiency.

the efficiency of the solar collector. It is clear that as the ratios of baffle spacing to collector length was reduced the efficiency of collector were greatly increased, however, when the ratios become small (many baffles), the efficiency was reduced. This is due to the fact that, in collector without baffles (ratio of 1), there was the direct passage of air in the medium of the collector from the inlet toward outlet which was associated with many dead zones and therefore reducing the effectiveness of the collector.

On the other hand, when there is less number of baffles in the collector, in this case, less than 4 , there was a high influence in heat transfer while pressure drop was insignificant. However, when baffles exceed this number, the associated increase in pressure drop was becoming higher than the heat transfer coefficient which results into insignificant increase in efficiency.

For the best performance, a number of baffles should be optimized to ensure the increase in collector efficiency is economical in order to avoid a high increase in air pumping power.

The study conducted [24] recommended the number of baffles ranging from 6 - 12 for the collector with dimensions $2 \mathrm{~m} \times 1 \mathrm{~m}$ and which occupies $60 \%$ $80 \%$ of the collector width. Therefore, according to the reported studies and the results obtained, the number of baffles in the model $1.2 \mathrm{~m} \times 0.6 \mathrm{~m}$ should range from 2 - 4 baffles. However, performance increment of $4.3 \%$ obtained in 4 baf- 
fles collector was out of range of $7 \%-12 \%$ [25]. This was due to the fact that, in the collector used by the author in his study, the air was passing inside the tubes which were a good conductor of heat while the models reported in this study air was passing through the collector duct. It was also reported that increase of pressure load because of the close spacing of baffles is not a problem for low airflow rates and recommended that, the increase in pumping power should not exceed one-tenth of the useful power of the collector.

\section{Conclusions}

- Thermal efficiency of air flat plate solar collector with different numbers of buffles has been successfully studied and compared to conventional collectors.

- Installation of buffles in the air passage gives a promising aproach in tackling the effect of dead zones in the collector and hence improves the overall efficiency of the system.

- The optimum number of baffles has to be considered during design to avoid excessive effect in pressure drop which will increase the operation cost.

\section{References}

[1] Rabha, D.K., Muthukumar, P. and Somayaji, C. (2017) Energy and Exergy Analyses of the Solar Drying Processes of Ghost Chilli Pepper and Ginger. Renewable Ener$g y, 105,764-773$. https://doi.org/10.1016/j.renene.2017.01.007

[2] Kumar, M., Sansaniwal, S.K. and Khatak, P. (2016) Progress in Solar Dryers for Drying Various Commodities. Renewable and Sustainable Energy Reviews, 55, 346360. https://doi.org/10.1016/j.rser.2015.10.158

[3] Bala, B., Mondol, M., Biswas, B., Das Chowdury, B. and Janjai, S. (2003) Solar Drying of Pineapple Using Solar Tunnel Drier. Renewable Energy, 28, 183-190. https://doi.org/10.1016/S0960-1481(02)00034-4

[4] Lingayat, A., Chandramohan, V. and Raju, V. (2017) Design, Development and Performance of Indirect Type Solar Dryer for Banana Drying. Energy Procedia, 109, 409-416. https://doi.org/10.1016/j.egypro.2017.03.041

[5] Akoy, E.A.O.M., Von Hörsten, D. and Luecke, W. (Eds.) (2008) Drying Kinetics and Colour Change of Mango Slices as Affected by Drying Temperature and Time 2008.

[6] Aljuamily, K., Khalifa, A. and Yassen, T. (2007) Testing of the Performance of a Fruit and Vegetable Solar Drying System in Iraq. Desalination, 209, 163-170. https://doi.org/10.1016/j.desal.2007.04.026

[7] Shahsavar, A. and Ameri, M. (2010) Experimental Investigation and Modeling of a Direct-Coupled PV/T Air Collector. Solar Energy, 84, 1938-1958.

https://doi.org/10.1016/j.solener.2010.07.010

[8] Banout, J., Ehl, P., Havlik, J., Lojka, B., Polesny, Z. and Verner, V. (2011) Design and Performance Evaluation of a Double-Pass Solar Drier for Drying of Red Chilli (Capsicum annum L.). Solar Energy, 85, 506-515. https://doi.org/10.1016/j.solener.2010.12.017

[9] Sharma, A., Chen, C.R. and Vu Lan, N. (2009) Solar-Energy Drying Systems: A Review. Renewable and Sustainable Energy Reviews, 13, 1185-1210. 
https://doi.org/10.1016/j.rser.2008.08.015

[10] Bennamoun, L. and Belhamri, A. (2003) Design and Simulation of a Solar Dryer for Agriculture Products. Journal of Food Engineering, 59, 259-266. https://doi.org/10.1016/S0260-8774(02)00466-1

[11] Mulokozi, G., Mselle, L., Mgoba, C., Mugyabuso, J. and Ndossi, G. (2000) Improved Solar Drying of Vitamin A-Rich Foods by Women's Groups in the Singida District of Tanzania. International Center for Research on Women.

[12] Weiss, W. and Buchinger, J. (2009) Solar Drying.

[13] Janjai, S., Srisittipokakun, N. and Bala, B. (2008) Experimental and Modelling Performances of a Roof-Integrated Solar Drying System for Drying Herbs and Spices. Energy, 33, 91-103. https://doi.org/10.1016/j.energy.2007.08.009

[14] Vriens, M. and Van Diesen, G. (2007) Tanzania, the Implementation of an Innovation for Sustainable Economic Development in Rural Areas: The Case of Solar Fruit \& Vegetable Drying in Rural. Thesis.

[15] Karim, M. (2004) Development of Solar Air Collectors for Drying Applications. Energy Conversion and Management, 45, 329-344. https://doi.org/10.1016/S0196-8904(03)00158-4

[16] Akpinar, E.K. and Koçyiğit, F. (2010) Energy and Exergy Analysis of a New FlatPlate Solar Air Heater Having Different Obstacles on Absorber Plates. Applied Energy, 87, 3438-3450. https://doi.org/10.1016/j.apenergy.2010.05.017

[17] El-khawajah, M.F., Aldabbagh, L.B.Y. and Egelioglu, F. (2011) The Effect of Using Transverse Fins on a Double Pass Flow Solar Air Heater using Wire Mesh as an Absorber. Solar Energy, 85, 1479-1487. https://doi.org/10.1016/j.solener.2011.04.004

[18] Kabeel, A.E. and El-Agouz, S.A. (2011) Review of Researches and Developments on Solar Stills. Desalination, 276, 1-12. https://doi.org/10.1016/j.desal.2011.03.042

[19] Mbise, E. (2008) Design of an Efficient Box Type Solar Dryer for Fruits and Vegetables. Dares Salaam.

[20] Kalogirou, S.A. (2004) Solar Thermal Collectors and Applications. Progress in Energy and Combustion Science, 30, 231-295. https://doi.org/10.1016/j.pecs.2004.02.001

[21] Zambolin, E. and Del Col, D. (2010) Experimental Analysis of Thermal Performance of Flat Plate and Evacuated Tube Solar Collectors in Stationary Standard and Daily Conditions. Solar Energy, 84, 1382-1396.

https://doi.org/10.1016/j.solener.2010.04.020

[22] Aldabbagh, L.B.Y., Egelioglu, F. and Ilkan, M. (2010) Single and Double Pass Solar Air Heaters with Wire Mesh as Packing Bed. Energy, 35, 3783-3787. https://doi.org/10.1016/j.energy.2010.05.028

[23] Velmurugan, P. and Ramesh, P. (2011) Evaluation of Thermal Performance of Wire Mesh Solar Air Heater. Indian Journal of Science and Technology, 4, 12-14.

[24] Romdhane, B.S. (2007) The Air Solar Collectors: Comparative Study, Introduction of Baffles to Favor the Heat Transfer. Solar Energy, 81, 139-149. https://doi.org/10.1016/j.solener.2006.05.002

[25] Pona, J. (1985) Increasing Thermal Efficiency of Solar Flat Plate Collectors. NASA STI/Recon Technical Report.

[26] Abene, A. (2004) Study of a Solar Air Flat Plate Collector: Use of Obstacles and Application for the Drying of Grape. Journal of Food Engineering, 65, 15-22. https://doi.org/10.1016/j.jfoodeng.2003.11.002

[27] Yeh, H.M., Ho, C.D. and Lin, C.Y. (1998) The Influence of Collector Aspect Ratio 
on the Collector Efficiency of Baffled Solar Air Heaters. Energy, 23, 11-16. https://doi.org/10.1016/S0360-5442(97)00054-6

[28] Struckmann, F. (2008) Analysis of Flat-Plate Solar Collector. Project Report, MVK160 Heat and Mass Transport, Lund.

[29] Luna, D., Jannot, Y. and Nadeau, J.-P. (2010) An Oriented-Design Simplified Model for the Efficiency of a Flat Plate Solar Air Collector. Applied Thermal Engineering, 30, 2808-2814. https://doi.org/10.1016/j.applthermaleng.2010.08.016

[30] Karatasou, S., Santamouris, M. and Geros, V. (2006) On the Calculation of Solar Utilizability for South Oriented Flat Plate Collectors Tilted to an Angle Equal to the Local Latitude. Solar Energy, 80, 1600-1610. https://doi.org/10.1016/j.solener.2005.12.003

[31] Ekechukwu, O. and Norton, B. (1999) Review of Solar-Energy Drying Systems III: Low Temperature Air-Heating Solar Collectors for Crop Drying Applications. Energy Conversion and Management, 40, 657-667.

https://doi.org/10.1016/S0196-8904(98)00094-6 